\title{
Empowerment of the Students Creativity Through Participatory Art Project in Surakarta
}

\author{
Adam Wahida \\ Graduate School of Indonesia Institute of the ArtsYogyakarta, Yogyakarta, 55000 Indonesia \\ email: adamwe91@yahoo.com
}

\begin{abstract}
The general objective of the participatory art project creation is to provide inspiration and concrete solutions to the creativity problems of senior high school students in Surakarta. While specifically aims to: 1 ) create useful the art strategies to empower the students creativity, 2) realize the art project that favors the development of students creativity potential, 3 ) create many artwork that comes from the students socio-cultural context. The methods of participatory art creation were done by: 1) an intensive on-site art project that was on going at SMAN 5 Surakarta, SMA Murni and MA Al-Islam in Surakarta. Object observation included student activities in and outside of school, the learning atmosphere in the classroom, student work documents, and documents teacher (curriculum, syllabus, lesson plans, learning materials). 2) In-deep interviews; with the head master, teachers, and students. 3) The literature review; to examine the theory to reinforce the concepts as a foundation that provides clear direction and path in the process of creating art works for the purpose of creating some participatory artwork. 4) Workshop and experiments; provide workshops of art creation to the students and conduct experiments with materials, techniques and formats in order to achieve a shape that corresponds to the concept of creation. The results of this art project are: 1) the product of participatory art creation strategies that are able to empower the students creativity. 2) the realization of participatory art project moving in the area of art creativity empowerment of students in the school. 3) the creation of art works based on the socio-cultural context, namely: print making, comic strips, comic puppets, etching. Through the creation of a participatory art project has been a change as follows: 1) An increase in the students activity receiving learning material of art creation, especially of the creativity led to the idea in visual forms. 2) Participatory art project can be oriented to direct experience of completing a variety of problems from simple. 3) The students have a skills to creative thinking with a different perspective and can be flexibly applied to solve a of problems as well welcoming the opportunity.
\end{abstract}

Keywords: participatory art, students, creativity.

\section{INTRODUCTION}

In 2010, I was doing research at several high schools in Surakarta. The results of these research indicate that the implementation of art learning, especially the subject matter creation/expression is still done conventionally, because students are only taught technical skills by imitating the teacher. In this case the student as 'forced' to do the activities that they do not necessarily like it. This happens because in implementing the learning, the teacher only vertical thinking. This way of thinking is choose the approach that sequentially, exact at every step so the construction of learning tend to be rigid, instructional, not explorative and boring. This condition is shown on the behavior of students who pay less attention to the teacher, chose to have a chat with 
friends and art learning considers as free time to rest before following the next lesson. Conventional learning is motivated by: 1) a lack of knowledge, understanding, and creativity of teachers in developing the model, material and methods of learning, 2) teacher only orients the achievement of student learning outcomes in knowledge without seeing any further goals as student life skills, especially creativity power. (Wahida, 2010: 73).

As an artist and art teacher at teacher colleges, I have a moral responsibility to always care about the social environment, in this case the development of young people (students) creativity. Thus the search of various models and art learning strategies that can evoke of creativity, be a challenge that must be solved. Instinctively, the phenomenon of the art learning implementation that occurs in the school, always disturbing my mind.

\section{MATERIALS AND METHODS}

In art, an artist can not be viewed as an individual solely because he is basically a society member. He lives and function in society and its culture. Thus the interaction between the society members (as a cultural buffer) in a variety of models of social relations will affect the creative process of the artist. According to Kayam (1981: 39) art never stands be separated from society. As one important part of the culture, art is an expression of creativity of the culture itself. The society supporting of culture and arts similarly is able to provide the opportunity to move, nurture, transmit, developing for then creating a new culture again.

In line with the above thinking, responsibility as an artist and art educator for resolving the social environment, must be solved. Art learning phenomenon that occurs in senior high school especially in an effort to creativity empower has inspired and sparked the idea of creating my art. Based on this awareness, I do self-liberation associated with the creative process. Thus to do search arts strategies that is able actively involving the social dimension, not only as a tool the borrowed by artists to create works, so there is a real contribution which is done through the arts movement.

Steps to be taken to answer the above problems is creating a participatory art project with high school students in Surakarta. Through participatory art project will be able to open up the energy and give each other a chance to communicate with each other, which then be able to unify the experience and vision and encourages creativity stimulation. In the empowerment of creativity, I will be able to see a variety of possible strategies, models, and methods of creating art. Art project based on the spirit of alignments on the creativity of the students is to give an alternative solution in addressing the phenomenon of art learning in senior high school also became a offer of new art creation model.

The creation of a participatory art project is an unease accumulation on the phenomenon of neglected students' creativity in the art learning process in the school. Art learning in schools is less than optimal became the subject matter. Expected through the creation of art project will be a model of creative and solutional to empower creativity. Thus the specific problems in the creation of art project, 
formulated as follows: 1) How to create the art project model which is based on the students creative potential? 2) How to create an art project that capable to developing students creativity? 3) How to create an art work that is sourced from the sociocultural context of the student?

In contemporary art, participatory art practice began to receive attention in the praxis and discourse. The presence of participatory art in the arena of modern Western art, is a form of resistance to the elitism of art that appear, when the discourse of art only an interests dominated (artist-gallery) while communities to take only become consumers. Participatory art emerged as an alternative that gives the possibility for the general public to be part of the the creation of art work. Participatory art is often called the interactive art, engage the audience/participants to become part of the artistic process in various ways. Engage the audience/participants to mix things asked by the artist per section, or even be part of the overall artistic work.

Observing practice, participatory art has a lot of understanding basic in the theory and practice. But the simple participatory art can be said that the artists working together with a community of people, where they take part in the creation process of the artist's work. Because it involves many people in a community, the art practice of many involves inclination of creating works. The artist became the center of all creative processes conducted. This practice is a multifaceted art practice, involving many understanding of artistic practice disciplines. Because it involves the many individuals with different artistic understanding, practices qualifying are also different, certainly raises many of significance in a participatory art work. So in participatory art, creativity exploration from each individuals involved in it becomes the main focus in the the creation of artist's work.

\section{Pablo Helguera, Art as a Social Activity}

Relating with participatory art, there are several theories that can be used to view the spectrum of ideology-praxis of this art activity. Pablo Helguera perspective in Education for Socially Engaged Art, Jorge Pinto Book 2011 became the basis of interesting to see how the participatory arts is an option to make art as a social practice (socially engaged art). He argued that, art in the paradigm of modern have a position that 'isolated' from the context of social practices. This is due to the practice of making art by artists tend to be conventional and is from the practice of other sciences, such as Sociology, politics, and the like. Art just take the vertices of issues and represented in the form of work, rather than in a more tangible activity. Although the practice of the art with the sciences another long-standing, however when the discussion between the two branch of science is brought in a wider sphere, for example in the social practice never found a clear action point.

While this is also influenced by the dilemma that occurs within artists when they have to deal with the art paradigm that built by the market. Artists working in the realm of social practice, must continue to define the idea, write it down, and affirm its existence in the realm of art, as artists. Although sometimes they do work like anthropologists, sociologists, and so on. On the basis of 'art elitism' and to bridge art practices tendency 
that came out of this conventional line, Pablo Helguera asserted that the practice of these artists in the term 'socially engaged art' /SEA. This term emerged in the mid1970s, as the bridge of the art in the social work area.

Furthermore, Pablo Helguera said there are two important differences in an art practice that is: the symbolic and actual. Art practice of SEA is more emphasize on the actuality and practical work, not symbolic. Many art works were done by artists who are motivated politically or socially in a community, but they acted through a representation of an idea or problem. In the result, the work of which they are designed to deal with matters of social or political level only in allegorical, metaphorical, or symbolic. For example, a painting about social issues is also claiming to offer a social experience, but only do it on a symbolic level.

Art as a social activity is not a manipulative activity to achieve a certain goal, but more than that, communication which the art activities is able to direct on understanding each individual involved to understand the political and cultural context, lead to emancipatory attitudes. Thus artists to produce art collective impact on the public sphere in a way that is deep and meaningful, instead of creating representations of social problems alone.

It is true that many participatory art practice take action and movement of symbolically, for example; create a mural or sign-art in the village, but the important thing is not the mural, but how the interaction with the community. Create a mural is a symbolic act, but it is not a symbolic practice. Symbolic action is act which emphasizes aspects of communication, or the actual art activity. In summary, social interactions occupies central part and inseparable of any socially engaged art. SEA is a hybrid, multi-disciplinary activities between art and non - art.

Relating with participatory art, Pablo Helguera gives a spectrum which has some of the same elements. The spectrum ranged on: 1) Nominal Participation (participant reaction when confronted with an object/idea), 2) Artists Participation (when an artist gives a simple task to be done by participants, such as the make a wish and write it down), 3) Creative Participation (when participants are responsible for producing some creative content), 4) Collaborative Participation (when participants share the responsibility for developing the structure and content of the work).

\section{Grant H. Kester, Participatory Art as a Dialogic Practice}

The next perspective with regard to participatory art is thoughts of Grant H. Kester on 'dialogical practice' in the creation of art works. Regarding this dialogic practice he reveals that the art practice shifted which art has been the object, the practice of making art as an activity that is open, there is exchange of thoughts and interactions process more extensive.

In his book The One and the Many: Contemporary Collaborative Art in a Global Context, 'dialogic practices; This explicitly interpreted as advocating act to perform collaborative work, that is politically presenting artwork that blurs the line between community activity and the creation of works of art. Kester defines collaborative work as a reflection of the status of 'creator' in self an artist, challenge the notion of aesthetic 
autonomy, and the interactions that occur between artist-artwork-audience.

Kester idea rests on 'relational aesthetics' that was developed by Nicolas Bourriaud (1998). A term that emerged in the mid 1990s to the artist who creates interactive installations or multi-sensory and emphasize the possibility of social exchange within them. French art critic Nicolas Bourriaud coined the term and described it as "a set of artistic practices that take as a point of departure theoretically and practically whole of human relations and their social context."

Relational aesthetics was first used by Bourriaud on 1996 for the exhibition catalog 'Trafict' at CAPC Musée d'Art Contemporain de Bordeaux. Relational Aesthetics celebrate art as experience, defines art as a set of participatory meetings not only as objects of art, as exemplified by the work of Thomas Hirschhorn, Pierre Huyghe, and Rirkrit Tiravanija. Participatory art in Kester thinking is a trend that is not strictly in view of art and politics, as is the reference in the conventional art practices. Participatory art work has certain functions to generate social change through creative collaboration.

\section{Principles of Participatory Art}

Based on theoretical understanding of participatory art the above, I formulate some principles of participatory art that can then be used as a benchmark in doing the work of participatory art creation.

1. Participatory art allows each individual involved to explore things that are interesting and meaningful to their lives. Because the basic conception of the activity of this art is a creative process where artists and participants were able to produce meanings together. This means, the artist worked with individuals or groups to explore ideas that are meaningful to their and how to interpret the things that have been made.

2. Participatory art focuses on creativity that is both challenging and has a compelling power for artists and participants. Every creative process that is executed should be able to evocative consciousness of every individual, to see something that is meaningful to their lives today. Therefore art activities undertaken should prioritize the ways in a creative, non-linear, to explore the creative potential during this sometimes overlooked. It is very important to fosters an alternative perspective on the self identity and others, that will be shown by the spontaneity attitude, the use of language, symbols and images taken in the artwork that they create.

3. Participatory art understand that the a person's identity is how a person tells themselves about himself. An awareness efforts to understand that identity is constructive, determined by people that sometimes very forced. Therefore, participatory art became a way to help individuals exploring and contemplating each of its potential and how to communicate it to others. Participatory art is an activity that uses art practices to empowering communities, reflecting every individual involved as part of the culture, while helping to build their identity.

4. Participatory art is actual and contextual. An activity that emphasizes of selfunderstanding, potential exploration of experience and individual identity. Artists and participants understand the context of their existence in the social sphere of society and culture. The raw material of participatory art project is a certain experience of the participants and artists. Both must find a way to reveal it. 
5. Participatory art is process of together creative exploration, as well as learning spaces for artists and participants. Understand that the each individual has a creative potential, knowledge and skills. They mutually formulating questions that will become the guidelines of the art practice that will be done. Finding the idea of the phenomena that occur in daily life. This principle asserts that the work of participatory art based on process. Understanding of this variety is an intrinsic value that would be realized in a variety of artistic products. Participatory art does not just focus on the product, but also on 'the traces left by the art' itself.

In this method of art creation, I positioned myself as an artist expand, seek and explore with students about theories, discourse and creating methods of participatory art works. According to Melvin Rader in 'The Meaning of Art' (Yustiono translation, 1986) art as a creative act, very fluid and open, and no restrictions are tight enough for wise to line. This is due to too many crossing and linkage between human diversity, art, religion, technology, economy and so on.

Art creation method followed by structured stages and unpredictable steps, spontaneous and intuitive. Therefore, in this participatory art creation, in general I use the following methods:

\section{Engaged Observations}

Engaged observations carried in various activities related to the art learning problems, such as the organization's activities and learning activities. This is done in order to obtained an understanding of the processes and actions of an object under study (Spradley, 1980: 53-58). Type of data collection have been selected on the grounds that by observation involved is much better, even enables the obtaining of complete data, when compared with doing the interview (Gateword, 1985: 215). However, the procedures offered by the two experts these not the only framework that leads, because the role of the tool itself (research instrument) is more important, especially in negotiating conditions enables the data or information that is more accurate (Bogdan $\&$ Tylor, 1982 : 33). This observation techniques used to collect data related to the ideas and creativity of teachers in implementing the learning to evoke the creative potential of students.

In the process of collecting this data I am engage in the process of art learning in school. However, where I am not as 'insiders' (those researched), but just trying to want to be 'insiders' are limited to the purpose to understand all the processes and events held during the observation. In this way it will not lose its essence, so that the limit as 'insiders' and as or 'outsiders' can still be maintained. It is very important to obtain the data sought objectivity. The population of this observation is senior high school students in Surakarta, and the artwork by students, learning activities, thoughts, activities places, and things that support the art learning activities. While the samples taken of some students from population of senior high school students in Surakarta. The population is subject of research, while the sample is the majority or representative of the population (Arikunto, 1991: 102-104).

Sampling technique conducted with a purposive sampling, the selected schools apply the subject matter of art. As for sampled schools namely: SMA Negeri 5 Surakarta, 
Surakarta Murni SMA, MA Al Islam Surakarta. The sample selection was based on input competitiveness in school, school infrastructure and teacher qualifications. SMA Negeri 5 were sampled to represent the enter school with high competitiveness and have a a special room for art lessons, MA Al-Islam and SMA Murni competitiveness represent the school with low entry and do not have a special room for learning art. As for sample class is a class $X$ with consideration that a class $X$ is a class in the beginning for high school students so that is expected continue to develop their creativity in the next class.

\section{In-dept Interviews}

A technique to complement the observation data is in-depth interviews (in-depth interviews). The interview process is conducted freely, by placing a situation and open process, informal and unstructured, but leads to a focus of research problems (Bernard, 1994: 213). However remain pursue data quality. Interview naturally more of ensuring that real information (Lincoln and Guba, 1985: 37).

To obtain the data in depth about the informant portfolio resources, is done by collecting biographical data (individual life-history), especially the activity data supporting the professionalism of teachers in the learning and creative activities. With techniques like this will make it easier to obtain a deep understanding, about things that are not easy to do with observation or observing from the outside (Pelto \& Pelto, 1987: 108-109; Koentjaraningrat, 1983: 59-72).

The process of in-depth interviews conducted to obtain an understanding of teachers role in arousing students' creative potential. Similarly other matters related to the students' creativity to create art works. This is done to complement the lack of data and to check the data carried with observations by involvement.

\section{Literature Review}

The study was conducted in order to examine the theory to reinforce the concepts as a basis that provides direction and way in the process of creating art works for the purpose of creating a participatory artwork. The data will be collected with this technique, the theory of participatory art movements including the concepts and methods of its creation.

\section{Workshop and Experimentation}

From a review of the concept and study of literature, I give art creation workshops to students and make experiments with materials, techniques and formats in order to achieve a shape that corresponds to the creation concept. Material and strategies of workshop based on the students needs in the context of teens socio-cultural. Thus matter and strategies of workshop according to the students psychological, and students can enjoy their involvement in this art project. 


\section{DISCUSSION AND RESULTS}

\section{A. The Art Project Model Based On Student Creativity}

To resolve the above problems, I prepared a draft of art project strategies that studentcentered. In this case the students need to be taught a way of thinking to generate ideas and creative works. Besides, students are given the freedom to manage the idea of the everyday environment. Visual culture of teens in Surakarta used as the basis to integrate with art lessons. The proper way to change the mindset of students about art lesson is to apply lateral thinking method. This method is believed to help awaken the imagination of the students is freely and unimpeded. Beside it can also give alternative of ideas related to the visual aspects is freely and are not confined by convention or common rules.

Lateral thinking is directly related to the search concepts and perceptions are diverse. In some ways changing perceptions and concepts are the basis of creativity that involves new ideas (Marianto, 2006: 120-123). Lateral thinking regard with to evoke new ideas. Lateral thinking also has a role in the break away from shackles of the old idea conception. This role generating attitude and approach to observe the problem in a different way. (Bono: 1991: 11-12). To build a common understanding in this art project, the concept of lateral thinking is used as the basis of participatory work. The strategy is to explain the concept of lateral thinking to the students bring up awareness on the meaning of each problem through a variety of perspectives. Once students understand how to think laterally and then given a workshop creating creative works are sourced from environmental and social context of the student as a teen in the community.

In the concept of lateral thinking-based learning, students are not only given the subject matter, but the creative thought process implanted to explore the potential of individual creativity in order to develop properly, and always grow in life. Each subject is a basic theme which must be developed by the students to look for other possibilities that could happen, how widely its development, will be in accordance with the potential and uniqueness of each individual.

Before determining the workshop materials, I and teachers unify perception of the importance of creativity, creativity and development barrier. The results as a basis for designing the workshop material so as not to deviate from the curriculum and students are able to facilitate expression. In addition, I identify various possible development through brainstorming approach. The approach is to look for as many workshop materials to be found more specific material.

The design of the workshop material is done by understanding and analyzing competence standards and basic competences in the curriculum. After getting the material in accordance with achievement of student competencies then the design method through a variety of perspectives. The main benchmark is that students have appreciative power that can trigger the rise of the creative potential, because it is the core of art learning implementation in school. 
Based on this insight, I create learning materials alternative that can construct the idea of the surrounding environment observation as well as introduce and bring art to everyday life through techniques variety. The workshop materials are selected that make comics, comics puppet, etching, woodcutt. These materials were chosen with consideration that a familiar the artwork diversity among students as visual attributes. While ideas of its creation derived from the socio-cultural of teens in Surakarta.

\section{B. Participatory Art Creation Process}

After conducting a variety of workshops series and experimentation, then I along with students carrying out the artwork creation process. Here is the artwork creation process done with participatory.

\section{Gubuk Grafis}

This art work creation begins with setting up a canvas size of $20 \times 30 \mathrm{~cm}$, stitched edges and each corners was given a red ribbons. The canvas pieces totaling 100 pieces. Once the canvas is ready, then I and the students choose hardboard cut that has been generated during the workshop on woodcut. Each hardboard is then printed on canvas that is already prepared. The process of printing that is done is monoprit with black ink. After all canvas printed, then set its visual composition and merged into one. Connection of each canvas is done by connecting the ribbons on canvas corners.
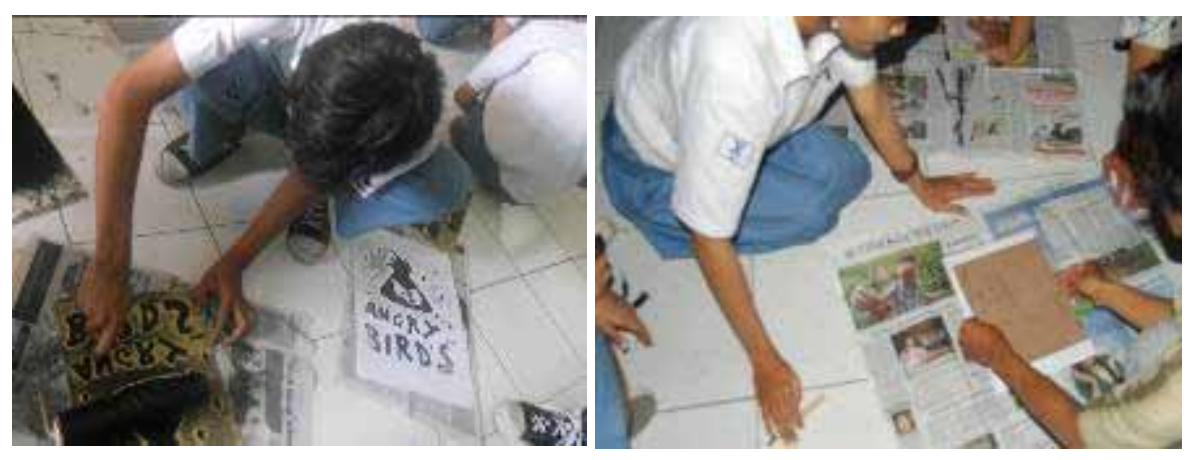

Figure 1. The process of printing on canvas (Collection: Adam Wahida, 2013).

After all canvas composed into a single, then the next process is to create a pole of wood to put the canvas to be easy set up like tent. The selection of tent shape was inspired by the tents used in extracurricular activities such as; scouts, outbound, camping. As such, conceptually the tent shape can be interpreted as a space to gather and creative activities for students. To complement the artwork force this Gubug Grafis, also presented the board/hardboard cut as its floor, while on the inside of tent arranged a table to put the graphic arts paper and LCD projectors that play video woodcut workshop process at some schools. 


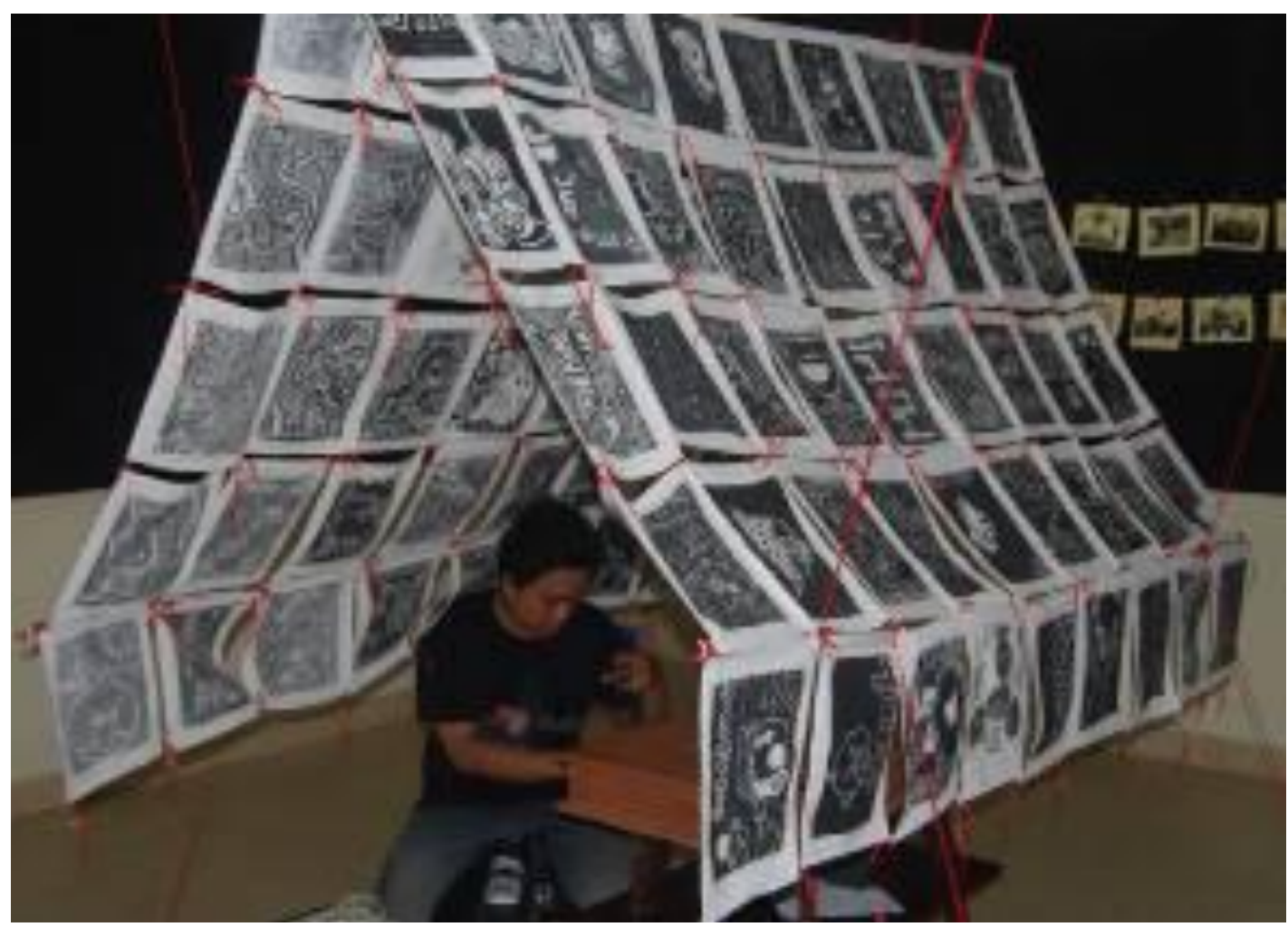

Figure 2. The process of organizing the inside of a tent. (Collection: Adam Wahida, 2013).

Visually, the work of graphic art is a ideas communication form between students who represented into a single unit. The practice of artwork creation is in line with the theory of relational aesthetics by Nicolas Bourriaud that art is a way to do exploration at the same media experiments on activities of communication between some people.

Compiling graphic artwork in the form of tent, printmaking paper put on the inside and play video shared work processes chosen as a model presentation. In addition to artistic considerations, all of the material into a single unit is presented to show a complete process of participatory work models that has been done. Art lovers are expected to understand and interpret each set of process shown through video documentation, as well as view the resulting graphic arts.

The selection this tent as a representation of the idea of the importance of a gathering space for students to express their creativity. The confidence of students who appear on each graphic art, demonstrate a complete personal creative expression. Students demonstrate cognitive ability for expressing ideas, creating patterns and styles, as well as expressing the spirit in the artwork.

\section{Expression of Etching}

The creation of this etching work begins with setting up a wooden board size of $10 \mathrm{x}$ $10 \mathrm{~cm}$ as a frame. Further etching produced during the workshop affixed on the board using a glue. Each board was given a hook at the top for hooking a rope hanger. 

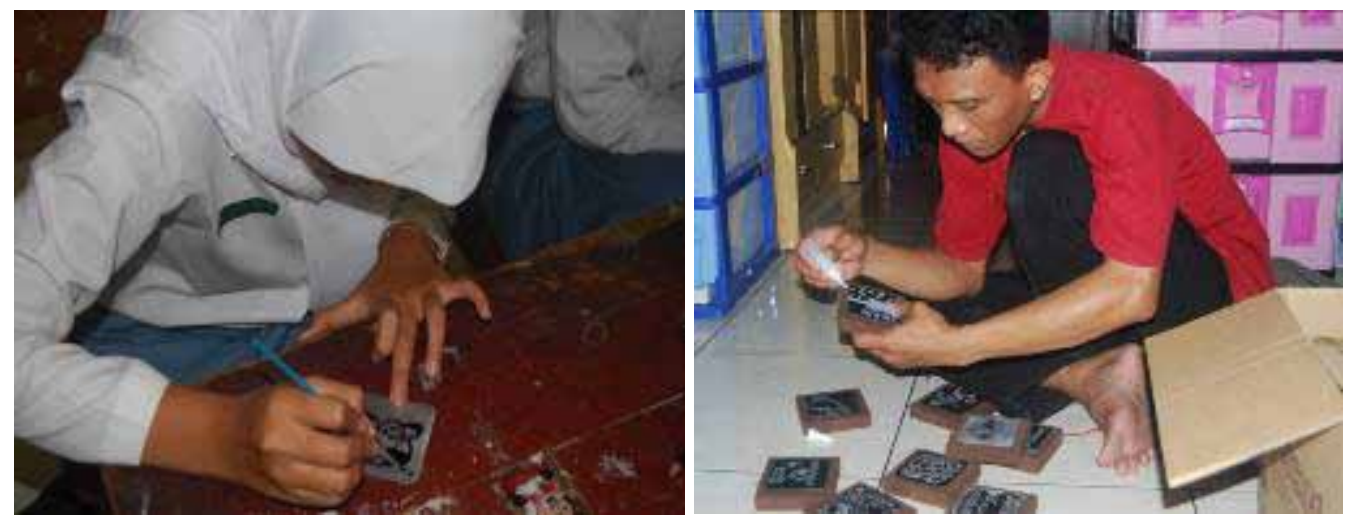

Figure 3. Making and installing the etching on wooden board (Collection : Adam Wahida, 2013).

Because of this artwork will be presented in the form of 2-dimensional installation, then I set up a hanger board of canvas size $140 \times 200 \mathrm{~cm}$, some nails fitted on the back of board for hooking a rope. The canvas is painted black and brown to resemble wood. When all is ready, the next etching board fitted red rope to hang on the canvas. Red rope to give contrast effect when arranged on black canvas. Compilation each etching on canvas is made randomly and unorganized to overlap one another. The idea of setting this artwork inspired by teens visual attribute setting such as pins, emblems, stickers, key chains, which are on display of randomly and overlap for sale in a store.
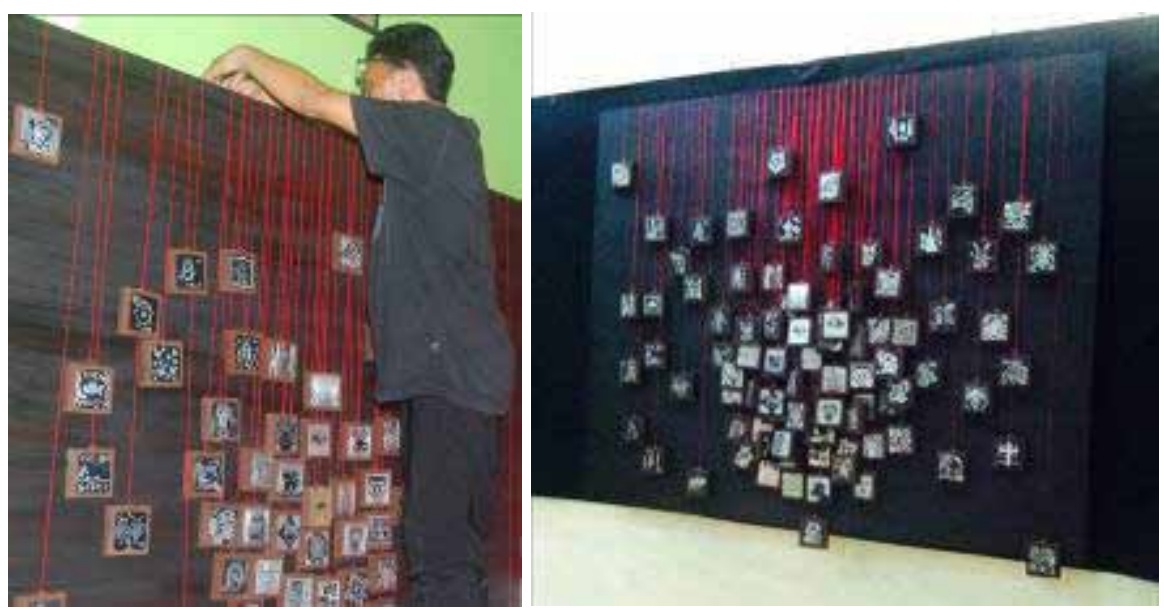

Figure 4. Thread installation and etching arrangement on canvas. (Collection : Haidar Ammar, 2014).

All etching randomly and piled presented, one with the other. In addition to artistic orientation, presentation like this to be symbolization so random and wild teens creativity of today's if not accommodated and facilitated. Accommodate all of etching in the canvas, became a symbol of that expression is random and piled it can be seen and facilitated.

This representation model also become sign that the current teens surrounded by popular symbols that obscure the meaning of self identity and communal identity, everything is overlapping and random. Efforts to accommodate the creativity of students is one way to identify their potential so that will bring up personal identities are strong. Through participatory work, these efforts done with students to bring 
up critical dialogue about the potential of creativity that is not accommodated. This participatory art project also become space to discover how each potential should be represented and accommodated.

\section{Documentation of Comic}

Through workshop of comic the students were able to make uniquely character comic pictures his own. Technical ability in drawing is not be a problem that hampers. Each student is able to develop imagination, build a story and present it. Comic the resulting from the workshop are presented in a book format. Its creation begins with the grouping based on the comic theme and visual tendencies. Due to these comic are made with different size then I put on the same paper size of $30 \times 40 \mathrm{~cm}$. After all comic tacked then arranged into 4 books. The final presentation of comic book each placed on a wooden pedestal shaped a cross. This presentation as well as documentation of the workshop process that has been done.

In addition to the format presented in the book, this comic is also presented in a 2-dimensional panels are made with cut-out technique. Each character image affixed to the sponge and then cut at the edges. pieces of the character images are grouped and affixed on a bigger sponge. To add to artistic value, ornamented background on sponge are made with a cutting technique. This is in addition to add to artistic value, is also a space to put a tagline which I was able to represent the whole set of pictures of this comic.
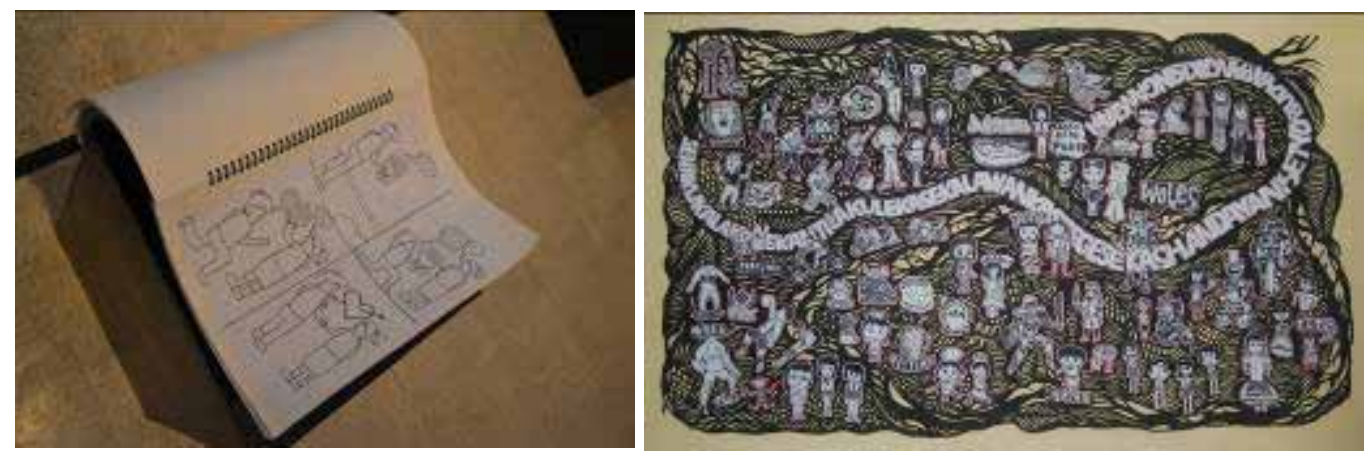

Figure 5. Presentation of comic book and panel. (Collection : Adam Wahida, 2014).

The selected tagline is "Seni Iku kalakone Kanthi Laku, Lekase Kalawan Kas, Tegese Kas Handayani, Setya Budya Pangikising Durangkara". This text is taken from the famous excerpt of Serat Wulangreh: 'Ngelmu iku kalakone kanthi laku, lekase kalawan kas, tegese kas nyantosani, setya budya pangikise durangkara' means that science can be understood /controlled must be trying hard to strengthen the character, strength of character to keep away from the evil nature.

\section{Comic Puppet}

This comic puppet is the result of the development of the previous comic workshop. The idea was inspired by the unique puppet shape and the freedom the comic shape. The unification of the two will bring a more unique visual form. The shape idea of each character is taken from the story of everyday life, such as: political issues, economics, pop culture, poverty, and unemployment. 

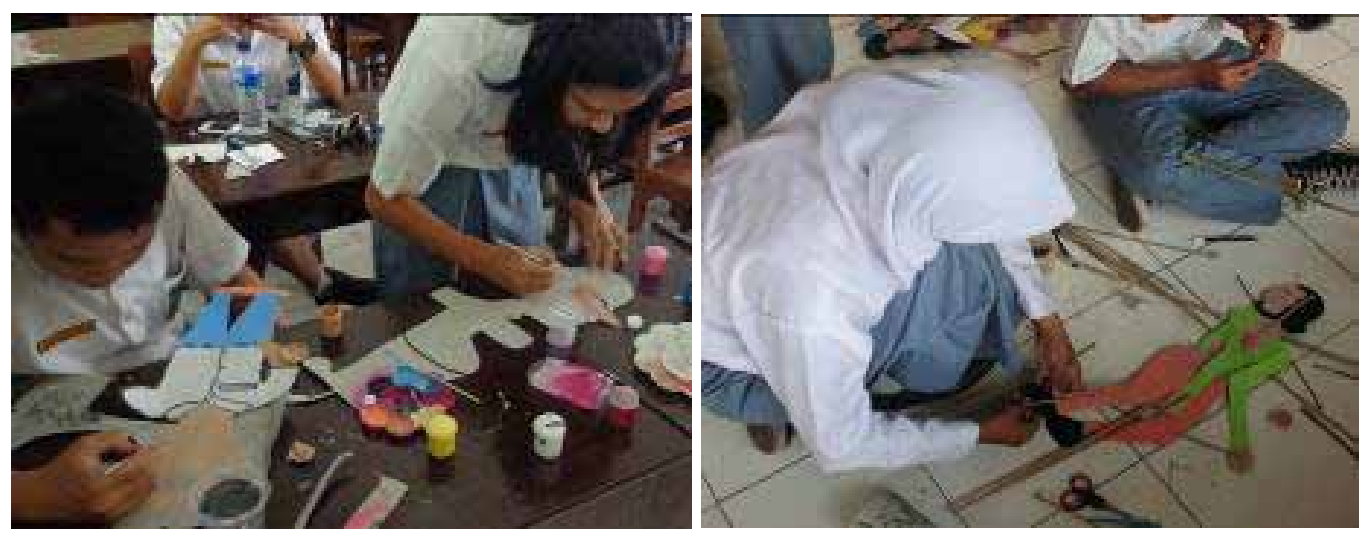

Figure 6. Students are coloring and put the handle of puppet. (Collection: Adam Wahida, 2014).

The creation of the artwork is started collecting comic puppet types and shapes that have been made. The presentation of an interactive artwork is created using a simple kinetic energy. Kinetic techniques have been selected to represent the proximity of the students to the environment. An interactive presentation through manual kinetic energy is expected to be the audience feel closer to the expression of these teens.

Puppet driven by wheels of wood a number of 20 pieces. The wheel was given axis, on each its axis are connected using a wood as long as $300 \mathrm{~cm}$. Length of wood that is used to put the handle of puppet. For driving force, one wheel was given a handle so that if one wheel is driven then all the wheels will move. Next I made a rectangular wood construction a number of 2 pieces the size of 100x $300 \mathrm{~cm}$, and 200x $300 \mathrm{~cm}$. The wood construction made like multilevel racks, large size is placed on the front and a small one in the back. The next series of wheels mounted on wood construction at the back. The series of the wheels, in the wheels part of most central added gear are connected with rotary handle using a chain. After buffer construction and wheels can be rotated, then each handle of puppet is placed on the wheels.

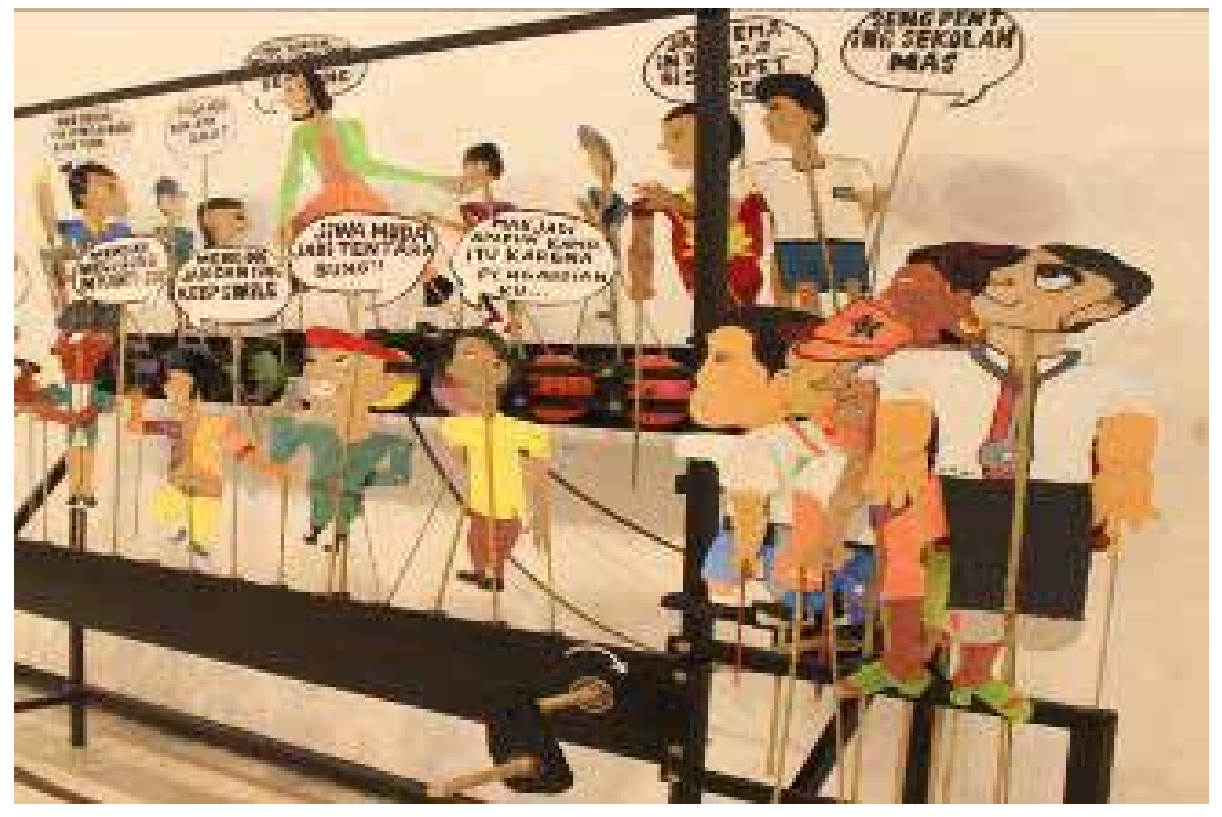

Figure 7. Position structuring comic puppet. (Collection: Adam Wahida, 2014). 
The idea of the form in this artwork is a sequence diorama. The story is not built in sequence, but more fragmented. Interpretation of story is left up entirely to the audience who saw it. The form of puppets and story taken from everyday stories that students encountered. Taking puppet motion techniques, comic characters and stories of everyday life is everyday reality manifestation of the typical teens. Representation techniques an interactive kinetic comic puppet is aimed to represent the tendency of teens creativity practices in Surakarta who live between tradition and modern culture.

\section{CONCLUSION}

The creation of a participatory art project is able to improve the art learning quality in senior high school. Through workshops series based on lateral thinking, students are able to explore ideas and the creative potential for creating artwork accordance to the soul. Through the creation of a participatory art project has been a change as follows:

1. An increase in the students activity receiving learning material of art creation, especially of the creativity led to the idea in visual forms. It is shown from a variety of visual forms created by each student independently, original, and accordance with the wishes and attention on an object.

2. The subject matter is more interesting because it emphasizes the involvement of students to observe a variety of things that are presented in the subject matter with many perspective so that the essence of their meaning can be found. This means that learning process can be oriented to direct experience of completing a variety of problems from simple.

3. Implementation of learning more encouraging students to understand meaning of the subject matter with linking in the context of everyday life (personal context, social, and cultural). Thus, students have the skills to creative thinking with a different perspective and can be flexibly applied to solve a of problems as well welcoming the opportunity.

\section{REFERENCES}

Arikunto,Suharsimi. (1991), Prosedur Penelitian. Suatu Pendekatan Praktik. PT. Jakarta : Rineka Cipta.

Bernard, Russel H. (1994), Research Methods in Antropology Qualitative and Quantitative Approach. USA: Sage Publication.Inc.

Bogdan \& Tylor. (1982), Dasar-dasar Penelitian Kualitatif. Terjemahan A Khozim Affandi. Surabaya:.Usaha Nasional.

Bono, Edward De. (1991), Lateral Thinking atau Berpikir Lateral, terjemahan Sutoyo.1991., Erlangga, Jakarta.

Bishop, Claire. (2012), Artificial Hells: Participatory Art and the Politics of Spectatorship, Verso, UK: 6 Meard Street, London.

Cammarota, Julio \& Michelle Fine (ed). (2007), Revolutionizing Education: Youth Participatory Action Research In Motion. Routledge, New York \& London.

Cooper, Mark and Lisa Sjostrom. (2007), Making Art Together: How Collaborative ArtMaking Can Transform Kids, Classrooms, and Communities, Beacon Press, Boston.

Lincoln Y and Guba, E.G. (1985), Naturalistic Inquiry. Beverly Hill: Sage Publications

Marianto, M.Dwi. (2006), Quantum Seni, Dahara Prize, Semarang.

Munandar, Utami. (1999), Pengembangan Kreativitas Anak Berbakat, Rineka Cipta, Jakarta. 
Nasution. (1988), Metode Penelitian Naturalistik Kualitatif. Bandung: Transito.

Pelto, Pretty J \& Gretel H. Pelto. (1987), Antropologycal Reaseach:The Structue of Inquiry. London: Cambridge University Press.

Wahida, Adam. (2010), Pengembangan Materi Pembelajaran Seni Rupa Berbasis Lateral Thinking dan Life Skill Untuk Meningkatkan Kreativitas Seni Siswa SMA di Surakarta. Laporan Penelitian DIPA BLU FKIP UNS.

\section{ONLINE RESOURCES}

Lowe, Toby. (2012), A Quality Framework For Helix Arts' Participatory Practice http:// www.helixarts.com/pages/research.html. accessed on May 2, 2014. 